\title{
sciendo
}

\author{
Current Issues in Pharmacy and Medical Sciences \\ Formerly ANNALES UNIVERSITATIS MARIAE CURIE-SKLODOWSKA, SECTIO DDD, PHARMACIA \\ journal homepage: http://www.curipms.umlub.pl/
}

\section{Reverse drug distribution in Poland}

\author{
Marek Stych ${ }^{1 *}$ (i), Beata PaWlica ${ }^{2}$ (i) \\ ${ }^{1}$ Institute of Law and Economics, Pedagogical University of Cracow, Poland \\ ${ }^{2}$ Faculty of Social Sciences, Institute of Political Sciences and Administration, Pedagogical University of Cracow, Poland
}

\begin{tabular}{ll}
\hline ARTICLE INFO & ABSTRACT \\
$\begin{array}{ll}\text { Received } 20 \text { April } 2021 \\
\text { Accepted } 20 \text { August } 2021\end{array}$ & $\begin{array}{l}\text { The trade and distribution of drugs or medicines (the two terms are used interchangeably } \\
\text { in the paper) has been evolving throughout the history of European pharmacy. In order } \\
\text { to ensure that EU citizens are safe, certain legislative measures had to be taken to prevent } \\
\text { Keywords: } \\
\begin{array}{l}\text { the illegal trade in drugs. The problem that affects the Polish pharmaceutical market } \\
\text { medicine trade, } \\
\text { pharmaceutical crime, } \\
\text { pharmaceutical wholesaler, } \\
\text { retail pharmacy. }\end{array}\end{array} \quad \begin{array}{l}\text { is the illegal export of medicines. The article attempts to analyse the so-called reverse } \\
\text { drug distribution, doing so by employing the dogmatic legal method. The paper ends with } \\
\text { de lege ferenda suggestions. }\end{array}$ \\
\hline
\end{tabular}

\section{INTRODUCTION}

The article tackles the issue of reverse drug distribution, and it discusses attempts to eliminate this practice as it violates national regulations, and the pharmaceutical entrepreneurs involved in such dealings violate the conditions specified in the authorization to conduct business activity on the pharmaceutical market. In Poland, drug distribution has been a strictly regulated area of economic activity. The entities participating in drug trade are licensed and the products permitted for sale are precisely stipulated by the law. Legal supervision in this respect is exercised by the bodies of the Chief Pharmaceutical Inspectorate [1]. The gravity of the risks posed by the reverse drug distribution is evidenced by the Guidelines of the Public Prosecutor General on the principles of conducting preparatory proceedings for offenses related to the mechanism of the so-called 'reverse drug distribution' [2]. The above-outlined illegal practices are performed by a number of business entities operating all over the EU. As a result, some EU citizens suffer shortages of the medicines they need [3].

\section{AIM}

The aim of the analyzes undertaken in the paper is to answer the question whether the so-called 'anti-export amendments' to the pharmaceutical law might possibly eliminate the irregularities without paralyzing the trade conducted legally.

\section{METHODOLOGY}

The scientific analysis of the above research problem was based on the dogmatic legal method, which consists of linguistic interpretations of the selected Polish and EU legal acts aimed at preventing the reverse drug distribution. The aim of the method used was to obtain answers to the following questions:

1. Have the aforementioned amendments succeeded in preventing reverse drug distribution practices?

2. Are the competent supervisory bodies of Polish public administration efficient enough?

\section{Reverse distribution of medicinal products}

The weight of the discussed issue can be demonstrated by the Preamble to Directive 2001/83/EC of the European Parliament and of the Council of 6 November 2001 on the Community code relating to medicinal products for human use [4]. This stressed the necessity to ensure the protection of trade in drugs. A sine qua non condition is to control the entire distribution chain from production or import into the EU, to dispensation, through ensuring appropriate storage, transport and circulation conditions for these products. Simultaneously, each wholesaler of medicinal products is obligated to obtain special authorization. Point (2) of the Preamble to the above-mentioned directive lays down the fundamental objective to be followed by the EU member states when establishing the legal framework for the functioning of retail trade in medicinal products. The following point of the Preamble points to the way this objective should be met - "by means which will not hinder the development of the pharmaceutical industry or trade in medicinal products within the Community". De lege ferenda, the EU law requires individual member states to design their regulations on trade in medicines in such a way so as to prevent 
drug trade irregularities, but simultaneously, not to hinder the lawful distribution de jure.

The term under analysis covers the illegal trade in medicines, which consists in buying them up from the retail market of a given country and then selling them abroad at a price several times higher than on the domestic market. It should be emphasized that the relatively low prices of medicines in Poland, especially that reimbursed, contribute to the attractiveness of export and force the producers to control the drug supply on the Polish market.

This, de facto, leads to a shortage of drugs on the retail market and hence their unavailability in pharmacies. The scale of the problem is evidenced by a list of drugs in short supply prepared by the Supreme Pharmaceutical Council submitted to the Ministry of Health. In July 2019, this list included 180 drugs that were not commonly available in pharmacies. These were medicines used in the treatment of thyroid diseases, diabetes, thrombosis, hypertension, asthma, epilepsy, migraine and depression. Not long after, in September 2019, the Ministry of Health published a new list of 350 drugs at risk of unavailability. In November of that year, the Ministry of Health published another list of 416 drugs at risk of unavailability in pharmacies. Clearly, the list of drugs in short supply was expanding relatively quickly.

The question arises whether all drugs are subject to this illegal practice on the Polish pharmaceutical market. In practice, the reverse distribution concerns mainly reimbursed medicines popular in Europe and produced by the largest pharmaceutical companies, original medicines and vaccines. The trade in generic drugs or substitutes of original drugs is affected by such practices to a lesser extent. As a result, some medicines are not available to Polish patients, but to entrepreneurs who export them. De jure, pharmacies operating in Poland legally may only sell medicinal products to patients, and wholesalers operating in Poland [5] cannot purchase medicines from public health facilities such as pharmacies. Pursuant to Article 37ap of the Act of 6 September 2001, the Pharmaceutical Law [6], an entity operating a pharmacy has to guarantee its proper functioning at all times. Hence, this obligation is binding not only at the moment of obtaining authorization to operate a pharmacy. Failing to guarantee that a pharmacy is operated within the law results in revocation of authorization de jure.

The validity of the above thesis can be illustrated with a decision of the Voivodeship Administrative Court in Warsaw [7]. The proceedings concerned the sale of medicinal products from a retail pharmacy to three pharmaceutical wholesalers. The provision of Article 72 - Paragraph 3 of the Pharmaceutical Law Act, which was of particular relevance in this case, stipulates that "wholesale trade is any action (...)". A linguistic interpretation of the cited provision allows one to conclude that wholesale trade also covers one-off transactions. Therefore, the Court rightly adjudicated that the entrepreneur had violated the fundamental principles that govern the functioning of a retail pharmacy and ceased to comply with the aforementioned legal condition stipulated in Article 37ap, that is to say, it failed to guarantee its proper functioning. What seems particularly dangerous is the practice of establishing healthcare entities whose sole purpose is to request medicinal products rather than treat patients. Such practices are undoubtedly designed to circumvent the law. However, the state pharmaceutical bodies do not currently have the legal power to supervise medical prescriptions [8] and the functioning of healthcare entities.

It should be noted at this point that it is the low prices of medicines in Poland, particularly those reimbursed, that increase the attractiveness of export and force the producers to control the supply of drugs on the Polish market.

\section{Legal protection of legal drug distribution}

The Polish legislator has taken legislative measures to ban reverse drug distribution practices. On 9 April 2015, the Sejm (the lower house of the Polish parliament) amended the Pharmaceutical Law Act [9]. Article 1 - Paragraph 10 gave a new wording to the provision of Article 86a: "Retail pharmacies or rural pharmacies are not allowed to sell medicinal products to pharmaceutical wholesalers, other retail pharmacies, or other rural pharmacies". Before the aforementioned act was amended, the state pharmaceutical inspection bodies had exercised supervision over the distribution of drugs based on the interpretation of the principle that "the trade in medicinal products may only be conducted under the terms specified in the Act" [10]. Ratio legis, this principle brings about certain consequences for entities conducting illegal activity, which has been emphasized by a number of authors [11]. The amendment of 12 July 2015 introduced a new penal provision, Article 126b, an interpretation of which allows one to conclude that the above-mentioned penalisation concerned only the entities selling medicines, not the entities purchasing them, such as pharmaceutical wholesalers. Therefore, in accordance with the Latin maxim executio juris non habet injuriam, the provision did not impose penalties on pharmaceutical wholesalers purchasing pharmaceuticals from pharmacies. Verba legis, the legislator created a legal loophole. Following amendments to Article $126 \mathrm{~b}$ penalized the activities of entities that:

- sell medicines violating the provisions of the Pharmaceutical Law Act;

- purchase medicinal products;

- purchase, sell, export, move or store medicinal products violating the relevant provisions of the Pharmaceutical Law Act.

The scale of the problem is evidenced by the Supreme Audit Office's report "Activities of state authorities to ensure the availability of medicinal products". According to the report's data, the total value of medicinal products sold to EU countries is PLN 3.5 billion, approximately 57\% of which are exported illegally. Therefore, the value of uncontrolled export of drugs as part of the reverse distribution practice is estimated at approximately PLN 2 billion [12].

The provision of Article 36g - Paragraph 1, Subparagraph 18 of the Pharmaceutical Law Act provides for an exhaustive list of the recipients of medicinal products sold by marketing authorization holders. The wholesale trade in medicinal products is reserved for pharmaceutical wholesalers who have obtained a license in accordance with Article 74 - Paragraph 1 of the aforementioned act. An obligation has been imposed on such entrepreneurs (Article 78 - Paragraph 1, Subparagraphs 1 and 3 of the said act) to purchase 
drugs only from bona fide producers or wholesalers, and supply these products only to authorized entities, the list of which has been provided for in the Regulation of the Minister of Health of 12 December 2002 on entities authorized to purchase medicinal products from pharmaceutical wholesalers [13]. It is justified to state that the Pharmaceutical Law Act does provide for effective mechanisms for combating the illegal export of drugs. One's intention to move medicines outside the territory of the Republic of Poland or sell them to an entity operating outside the territory of the Republic of Poland has to be now notified to the Chief Pharmaceutical Inspectorate who has the right to deny such a request. This stems from an increase in the number of reporting obligations related to the trade in drugs (the ZSMOPL system - Integrated System for Monitoring Trade in Medicinal Products [14]).

In order to further tighten the legal regulations, the Pharmaceutical Law Act was amended on 26 April 2019 [15]. The amendment resulted in a new wording of the provision of Article $86 \mathrm{a}$ - Paragraph 1. The new provision imposed an obligation on retail pharmacies and rural pharmacies to dispense medicinal products only as provided for in the Act and in the Act of 12 May 2011 on the reimbursement of drugs, foodstuffs for particular nutritional uses and medical devices [16].

The question arises as to how the trade in drugs ought to be conducted - in accordance with the law - in order not to disrupt certain business and operational goals, and at the same time, in order to minimize the risk of certain sanctions being imposed by a competent supervisory authority, e.g. revocation of license, fines, or criminal liability. In the broad sense, however, the provisions of pharmaceutical law ensure the safety of drug trade in Poland.

\section{Activities of entrepreneurs violating the legal drug distribution}

Such activities may lead to certain criminal consequences, stipulated in Article $165 \S 1$ - Subparagraph 5 of the Penal Code of 6 June 1997 [17], for bringing danger to the life or health of many people by impeding access to medicines saving life and health. In the literature, there are a number of activities performed by entrepreneurs involved in reverse drug distribution. In this regard, they use a variety of methods [18]:

1. Submit applications to pharmaceutical inspection bodies for suspending the activity of a pharmacy or pharmaceutical wholesaler, but at the same time keep conducting their illegal activities related to the trade in medicinal products.

2. Legally set up or take over additional wholesalers in order to extend the drug distribution chain.

3. Move drugs between pharmacies owned by the same entity (functioning under the same NIP - Tax Identification Number) and located in different voivodeships. The aim of such actions is to prevent the route of drug distribution from being determined.

An interpretation of point 3 seems problematic. For instance, if an audited entrepreneur owns a pharmaceutical wholesaler and a health care entity, the auditing inspector ascertains that the health care entity, like a patient, has the right to purchase drugs directly from a pharmacy. However, when there is a drug transfer between a health care entity and a pharmaceutical wholesaler, the drug distribution flow is undoubtedly disrupted, namely reversed, and this, according to the pharmaceutical inspection, is contrary to Article 86a of the Pharmaceutical Law Act. In the analyzed case, it seems apt to state that the auditing body goes beyond the provisions, violating the Latin legal maxim: clara non sunt interpretanda.

The interpretation of the Polish pharmaceutical law provisions allows concluding that medicines may be traded only between two separate entities, not within the organizational structure of one enterprise. The transfer of drugs between warehouses belonging to one enterprise does not have to be documented with a VAT invoice. The question therefore arises whether it is possible to regard such a practice as 'selling of drugs' and an instance of reversed drug distribution. There are two types of drug transfer in the Polish law: with and without a consideration. The sine qua non condition is that the transfer takes place between two entities operating on the pharmaceutical market. If one sells medicines to themselves, the ownership is not transferred to another person, only the place of storage is changed.

\section{CONCLUSIONS}

Having analysed the selected provisions relevant in the case of reverse drug distribution, it might be concluded that they are characterised by a high level of consistency. In support of this thesis, it should be mentioned that since 2015, legal attempts have been being made to eliminate reverse drug distribution. These include:

- new wording of Article 86a of the Pharmaceutical Law Act;

- Article 36g - Paragraph 1, Subparagraph 18 of the said Act - an exhaustive list of recipients of medicinal products sold by marketing authorization holders and manufacturers;

- Article 72 - Paragraph 3 of the said Act - the legal definition of wholesale trade;

- Article 78 - Paragraph 1, Subparagraphs 1 and 3 of the said Act - an obligation to purchase medicinal products only from bona fide manufacturers and wholesalers, and to supply such products only to authorized entities;

- Article 88 - Paragraph 5, Subparagraphs 5, 8 and 9 the pharmacy manager's tasks - purchasing medicinal products only from entities holding a permit to operate a pharmaceutical warehouse and dispensing them in accordance with Article 96;

- Article 86 - Paragraph 1 of the said Act - a pharmacy is a public health entity where authorized persons provide, in particular, pharmaceutical services;

- Article 87 - Paragraph 2 - retail pharmacies are designed to supply the population with medicinal products, officinal drugs, magistral drugs, medical devices and other articles.

- $\S 1$ - Subparagraph 1, Point 3 of the Regulation of the Minister of Health of 12 December 2002 on entities authorized to purchase medicinal products from a pharmaceutical wholesaler - a retail pharmacy should 
purchase medicinal products from a pharmaceutical wholesaler;

- Article $165 \S 1$ - Subparagraph 5 of the Penal Code - acting in a different way in particularly dangerous circumstances ("bringing danger to the life or health of many people by impeding access to life and healthsaving drugs").

The solutions adopted by the Polish legislator seem to be going in the right direction. Unfortunately, they have not solved the problem of reverse drug distribution in Poland. It seems that the panacea for this practice would be to fine-tune the system of control exercised over the main actors of the drug distribution process in Poland.

Since the above-discussed amendments have entered into force, it should be recommended to develop internal procedures for verifying the status of buyers and the quantity of purchased medicinal products. It is also important to train employees of pharmacies and wholesalers in the practical application of such procedures. De lege lata, the availability of medicinal products reflects the quality and 'depth' of legal solutions pertaining to the Polish pharmaceutical market.

De lege ferenda, it is recommended to:

1. Create so-called 'pharmaceutical police' authorized to efficiently and quickly inspect pharmacies and wholesalers, and to audit the sale of drugs via the Internet; online sale of medicines is in fact not controlled by pharmaceutical inspection bodies. This could be part of pharmaceutical inspection and resemble uniformed services. Its basic tasks would be, for example, to:

- identify, prevent and detect pharmaceutical offences;

- exercise the right to demand necessary assistance from state institutions, government and local self-government administration bodies, and entrepreneurs operating on the pharmaceutical market;

- initiate and organize activities aimed at preventing offences on the pharmaceutical market.

2. Increase the number of pharmaceutical inspectors carrying out audits of pharmacies and pharmaceutical wholesalers.

3. Fully implement the Integrated System for Monitoring Trade in Medicinal Products and ensure comprehensive monitoring of the trade in drugs that are short in supply.

4. Better coordinate the activities of the competent pharmaceutical inspection bodies, the Police and the Prosecutor's Office as regards supervision over entities conducting medical activity if:

- such entities are purchasing large amounts of drugs that are in short supply,

- it is suspected that those are not used to provide health services.

A sine qua non condition is that the competent supervisory authorities fully exercise their powers. The Chief Pharmaceutical Inspectorate's failure to inspect whether pharmaceutical wholesalers comply with their statutory obligations should be criticized, as it is the body's statutory obligation to do so. Another problem is that some Voivodeship Pharmaceutical Inspectorates fail to carry out audit plans. Finally, the Chief Pharmaceutical Inspectorate's policy regarding fines to be imposed on pharmaceutical enterprises also leaves a lot to be desired (Article 127d of the Pharmaceutical Law Act). An example may be the ineffective actions taken by the Chief Pharmaceutical Inspectorate in respect to [19]:

- discovering reverse drug distribution - 39 administrative proceedings have been initiated, however, none have resulted in withdrawing authorization to operate a pharmaceutical wholesaler;

- lengthiness of proceedings for issuing a decision objecting to the export of deficit drugs - 10 cases - more than two years after the intention to export deficit drugs had been notified, the Chief Pharmaceutical Inspectorate overturned the objected decisions and discontinued the proceeding in its entirety.

The body's refusal to impose fines is justified by the lack of tools allowing to determine an audited company's annual net turnover, which is necessary to determine the amount of fine [20].

To sum up, an integrated system of supervision and audit should be combined with an effective system of the enforcement of financial penalties, because currently the vindication of such liabilities does not function in practice [21]. It is mandatory for the bodies of the pharmaceutical inspection to fully exercise the competences devolved on them by the law. Therefore, it is necessary to urgently undertake further legislative actions and actions regarding the policies governing the Polish pharmaceutical market.

\section{ORCID iDs}

Marek Stych (Dhttps://orcid.org/0000-0003-4359-1085 Beata Pawlica (1Dhttps://orcid.org/0000-0002-2941-7470

\section{REFERNCES}

1. https://www.gov.pl/web/gif [access date: 18.04.2021]

2. https://sip.lex.pl/akty-prawne/akty-korporacyjne/zasadyprowadzenia-postepowan-przygotowawczych-o-przestepstwazwiazane-287346774 [access date: 18.04.2021]

3. The irregularities have been noticed by European agencies such as: The Heads of Medicine Agencies, the European Medicines Agency, and the Council and the European Commission. The problem of drug shortages in EU countries - pan-European research conducted by the European Association of Hospital Pharmacists (EAHP) - aimed at gathering information on emerging cross-border temporary drug shortages. https://www.eahp.eu/practice-and-policy/ medicines-shortages/2018-medicines-shortage-survey

4. OJ L 311; 28.11.2001. p. 67.

5. The Register of Permits for Operating a Pharmaceutical Wholesaler is kept by the Chief Pharmaceutical Inspectorate pursuant to Article 83 of the Pharmaceutical Law Act and the Regulation of the Minister of Health of 3 October 2012 on the description of the IT system for keeping the Register of Permits for Operating a Pharmaceutical Wholesaler. Journal of Laws of 2012, item 1118.

6. https://rejestrymedyczne.csioz.gov.pl/rhf/search/public [access date: 18.04.2021]

7. Decision of the Voivodeship Administrative Court in Warsaw of 6 June 2019 r., Case no. VI SA/Wa 116/19.

8. Medical prescription contains recommendations, orders, instructions and suggestions for the patient. It should be consistent with: 1. Requirements set by the law (and the Medical Code of Ethics), 2. Current medical knowledge.

9. The Act of 9 April 2015 amending the Pharmaceutical Law Act and certain other acts. Journal of Laws of 2015, item 788 . 
10. Article 65 - Paragraph 1 of the Pharmaceutical Law Act.

11. Czerw A, Bilińska M. Dystrybucja produktów leczniczych w Polsce w świetle regulacji legislacyjnych. Farm Współcz. 2012;5:116-25.

12. https://www.nik.gov.pl/kontrole/P/17/110/ [access date:18.04.2021]

13. Journal of Laws of 2002, No. 216, item 1831.

14. On 1 April 2019, the obligation to submit data to the Integrated System for Monitoring Trade in Medicinal Products entered into force. The Integrated System for Monitoring Trade in Medicinal Products makes it possible to monitor the trade at retail and wholesale level and report the gathered data to the competent authorities.

15. Journal of Laws of 2019, item 959.

16. Journal of Laws of 2021, item 523, 1292, consolidated text.

17. Journal of Laws of 2020, item 1444, as amended.
18. Najmoła D, Liszewski K. Eksport - import równoległy a odwrócony łańcuch dystrybucji leków. Kwartalnik Prawno-Kryminalistyczny. 2016;3(28):20.

19. Activities of state authorities to ensure the availability of medicinal products, Supreme Audit Office. Warsaw; October 2018. https://www. nik.gov.pl/plik/id,18813,vp,21416.pdf

20. The Chief Pharmaceutical Inspectorate has imposed financial penalties on entities participating in 'reverse distribution' to the amount of PLN 280 million (as of 31 July 2019) - unfortunately, no amount has been enforced.

21. Pursuant to the provisions of Article $299 \$ 3$ - Subparagraph 15 of the Tax Ordinance Act of 29 August 1997, Journal of Laws of 2019, item 900, as amended - the Chief Pharmaceutical Inspectorate is allowed to obtain information from the National Tax Administration, which is the basis for calculating the amount of fines. 